\title{
Sanksi Hukum terhadap Hakim Adhoc Pelanggar Kode Etik Profesi Hakim
}

\author{
Ratna Sayyida dan Suwari Akhmaddhian \\ Fakultas Hukum Universitas Kuningan, Indonesia \\ Email : ratnasayyida@gmail.com
}

\begin{abstract}
The purpose of this research is to find out how the code and conduct guidelines are set for judges and how to apply sanctions due to violations of the Code of Profession Ethics. The method of research used is normative, which is the method of approach by reviewing the laws that are conceptualized as the norm or the rules that apply to the community, and become the reference of everyone's behaviour. Data collection tools through library studies. Secondary use, i.e. data obtained through documentation studies by reading scientific books, magazines, internet, newspapers and other readings related to research. The results of the research are the settings regarding the code of ethics and the conduct of the judges as legal profession where the judges have obligations of liability or legal responsibility. So that all his deeds are supervised by law. Therefore, in his profession the judges must be neutral and will be the self-esteem and dignity of the judges so that the code of conduct and conduct of the judges can run properly
\end{abstract}

Keywords: Ethics; Law; Judge; Profession; Obligation.

\begin{abstract}
Abstrak
Tujuan penelitian ini adalah untuk mengetahui Bagaimanakah pengaturan kode etik dan pedoman perilaku bagi hakim dan bagaimana penerapan sanksi akibat pelanggaran kode etik profesi hakim. Metode penelitian yang digunakan adalah yuridis normatif, yaitu metode pendekatan dengan mengkaji hukum yang dikonsepkan sebagai norma atau kaidah yang berlaku dalam masyarakat, dan menjadi acuan perilaku setiap orang. alat pengumpul data melalui studi kepustakaan. yang digunakan sekunder, yaitu data yang diperoleh melalui studi dokumentasi dengan cara membaca buku-buku ilmiah, majalah, internet, surat kabar dan bacaan-bacaan lain yang berhubungan dengan penelitian. Hasil penelitian yaitu Pengaturan mengenai Kode etik dan pedoan Perilaku Hakim sebagai Profesi Hukum dimana hakim mempunyai kewajiban kewajiban atau tanggung jawab hukum. Sehingga segala perbuatannya diawasi oleh hukum. Karena itu, dalam profesinya hakim harus bersifat netral dan menjungjung harga diri dan martabat hakim sehingga Kode Etik dan Pedoman Perilaku Hakim bisa dijalankan dengan semestinya

Kata Kunci : Etika; hukum; hakim; profesi; kewajiban.
\end{abstract}

\section{PENDAHULUAN}

Pasal 1 ayat 3 Undang - Undang Dasar Negara Republik Indonesia berbunyi "Negara Indonesia adalah negara hukum". Sebagai Negara yang berdasar atas hukum (rechtsstaat) maka konsekuensinya segala yang terjadi harus didasarkan pada hukum. Dan sebagai negara yang menjunjung tinggi nilai hukum, maka Negara memberikan jaminan kekuasaan kehakiman yang merdeka. Penyelenggaraan peradilan dan kekuasaan kehakiman di Indonesia telah diamanatkan oleh Undang-Undang Dasar Negara Republik Indonesia Tahun 1945 kepada Mahkamah Agung [Pasal 24 ayat (1)]. Ketentuan mengenai kewenangan Mahkamah Agung diamanatkan oleh Undang- Undang Dasar agar dibentuk undangundang, yang dituangkan dalam Pasal 24 ayat (3), bahwa "Badan-badan lain yang fungsinya berkaitan dengan kekuasaan kehakiman diatur dalam undang-undang”.

\footnotetext{
${ }^{1}$ Achmad Miftah Farid, Hibnu Nugroho, Dwi Hapsari Retnaningrum, 2020. Pelaksanaan Fungsi Pengawasan Terhadap Perilaku Hakim Oleh Mahkamah Agung, Soedirman Law Review, Volume 2 No. 1 Tahun 2020. Purwokerto : FH UNSOED
} 
Logika : Journal of Multidisciplinary Studies, p-ISSN 2085-997X. e-ISSN 2715-4505.

Vol. 11 Nomor 02 Desember 2020. 68-78.

Hukum sangat erat hubungannya dengan keadilan, bahkan ada pendapat bahwa hukum harus digabungkan dengan keadilan, supaya benar-benar berarti sebagai hukum, karena memang tujuan hukum itu adalah tercapainya rasa keadilan pada masyarakat. Setiap hukum yang dilaksanakan ada tuntutan untuk keadilan, maka hukum tanpa keadilan akan sia-sia sehingga hukum tidak lagi berharga dihadapan masyarakat. ${ }^{2}$ Masyarakat berperan penting dalam mewujudkan hukum yang berkeadilan dimana Peradilan yang bersih adalah cerminan berjalannya hukum dalam masyarakat. Untuk mewujudkan peradilan bersih tersebut bisa diukur dari Independensi pejabat penegak hukum dalam hal ini adalah hakim. Kekuasaan kehakiman dijalankan oleh aparatur peradilan. Aparatur peradilan dalam menegakkan hukum dan keadilan tentu saja berpegang pada aturan atau pedoman berperilaku. Pengadilan yang mandiri, netral (tidak memihak), kompeten, transparan, akuntabel dan berwibawa, mampu menegakkan wibawa hukum, pengayoman hukum, kepastian hukum dan keadilan. Hal itu merupakan conditio sine qua non atau persyaratan mutlak dalam sebuah negara yang berdasarkan hukum. ${ }^{3}$

Dalam rangka penegakan hukum di Indonesia, hakim merupakan kunci utama dalam pengambilan keputusan yang adil dan bermartabat. Posisi hakim sebagai actor utama lembaga peradilan menjadi amat vital, terlebih lagi mengingat segala kewenangan yang dimilikinya. Melalui putusannya, hakim dapat mengubah, mengalihkan, atau bahkan mencabut hak dan kebebasan warga negara, dan semua itu dilakukan dalam rangka menegakkan hukum dan keadilan. Hakim merupakan kongkritisasi hukum dan keadilan yang bersifat abstrak, dan digambarkan bahwa hakim sebagai wakil Tuhan di bumi untuk menegakkan hukum dan keadilan. ${ }^{4}$ Namun yang terjadi sepanjang rentang tahun 2018 hingga 2019, Komisi Yudisial mencatat ada 6o rekomendasi sanksi bagi hakim yang diberikan kepada Mahkamah Agung. Menurut KY, ada dua alasan maraknya kasus pelanggaran Kode Etik dan Pedoman Perilaku Hakim (KEPPH) oleh para hakim. Alasan pertama, abainya MA terhadap integritas hakim karena lebih terfokus pada kemampuan kognitif. "Dalam pandangan KY, seharusnya aspek integritas masih menjadi hal dominan sebagai syarat sosok hakim yang ideal, memastikan rekam jejak seorang hakim, sama pentingnya dengan menjaga kepercayaan publik demi nama baik peradilan Indonesia. ${ }^{5}$

Salah satu kasus pelanggaran kode etik pada tahun 2019 yang dilakukan oleh seorang hakim adhoc, Syamsul Rakan Chaniago. Syamsul merupakan salah satu majelis hakim kasasi yang menangani kasus dugaan korupsi perkara korupsi penghapusan piutang Bantuan Langsung Bank Indonesia (BLBI) terhadap BDNI dengan terdakwa mantan Kepala Badan Penyehatan Perbankan Nasional (BPPN), Syafruddin Arsyad Temengung (SAT). Pada saat penenganan kasus tersebut Hakim Syamsul mengadakan pertemuan dan kontak hubungan dengan pengacara SAT dan atas alasan tersebut Syamsul Rakan Chaniago dikenakan sanksi etik. Berdasarkan kode etik dan perilaku hakim, hakim memiliki kewajiban dan tanggung

\footnotetext{
${ }^{2}$ Firman Floranta Adonara, 2015. Prinsip Kebebasan Hakim Dalam Memutus Perkara Sebagai Amanat Konstitusi, Jurnal Konstitusi, Volume 12, Nomor 2, Juni 2015. Jember: FH Universitas Jember

${ }^{3}$ H. Sudirman L, Hasanuddin Hasim, Abdul Hafid, 2019. Implementasi Kode Etik Dan Pedoman

Perilaku Hakim Di Ptun Makassar. Jurnal Hukum Samudra Keadilan Volume 14, Nomor 2, Juli-Desember 2019. Parepare : FHIS IAIN Parepare

${ }^{4}$ Al Wisnubroto, 1997, Hakim dan Peradilan di Indonesia, Universitas AtmaJaya Yogyakarta, Yogyakarta, hlm. 65 ${ }^{5}$ Devina Halim, KY Ungkap Dua Alasan Maraknya Pelanggaran Hakim, diakses di https://nasional.kompas.com/read/2018/o9/o6/21011321/ky-ungkap-dua-alasan-maraknya-pelanggaran-hakim, pada pukul 14.20 WIB 14 April 2020.
} 
Logika : Journal of Multidisciplinary Studies, p-ISSN 2085-997X. e-ISSN 2715-4505.

Vol. 11 Nomor 02 Desember 2020. 68-78.

jawab agar hukum dan keadilan itu ditegakkan, baik yang berdasarkan kepada tertulis atau tidak tertulis (mengadili suatu perkara yang diajukan dengan dalih bahwa hukum tidak atau kurang jelas), dan tidak boleh ada satupun yang bertentangan dengan asas dan sendi peradilan. Berdasarkan pemaparan diatas maka maka makalah ini akan membahas tentang pengaturan kode etik dan pedoman perilaku bagi hakim dan bagaimana penerapan sanksi akibat pelanggaran kode etik profesi hakim.

\section{METODE PENELITIAN}

Metode penelitian hukum, menurut Soerjono Soekanto adalah suatu kegiatan ilmiah, yang didasarkan pada metode, sistematika dan pemikiran tertentu, yang bertujuan mempelajari satu atau beberapa gejala hukum tertentu, dengan menganalisanya ${ }^{6}$. Metode penelitian yang digunakan adalah penelitian kepustakaan (library research) yaitu data sekunder yang diperoleh dari UUD 1945, Undang-Undang, hasil studi pustaka buku-buku, jurnal ilmiah, skripsi, dan referensi yang relevan.

\section{HASIL DAN PEMBAHASAN}

\section{A. Definisi Hakim Hak dan Kewajiban}

Sebagaimana dalam dimaksud dalam pasal 1 Undang-Undang Republik Indonesia Nomor 48 Tahun 2009 Tentang Kekuasaan Kehakiman. Hakim adalah hakim pada Mahkamah Agung dan hakim pada badan peradilan yang berada di bawahnya dalam lingkungan peradilan umum, lingkungan peradilan agama, lingkungan peradilan militer, lingkungan peradilan tata usaha negara, dan hakim pada pengadilan khusus yang berada dalam lingkungan peradilan tersebut. Hakim hanya patuh pada konstitusi dan hukum serta tidak tunduk pada komando dari lembaga yudisial atau lembaga non-yudisial lainnya. Badan-badan kehakiman/peradilan merupakan salah satu dasar terselenggaranya pemerintah yang demokratis di bawah Rule of Law sebagaimana pemikiran mengenai negara hukum modern yang pernah dicetuskan dalam International Commission of Jurists di Bangkok tahun $1965 .{ }^{7}$ Hakim merupakan profesi luhur yang diikat dengan Etika Profesi. Berbeda dengan profesi luhur, profesi hakim memiliki keistimewaan karena karya profesinya selalu diberikan legitimasi sebagai kebenaran yang harus diterima. Legitimasi merupakan ini tidak dapat dikalahkan oleh kekuatan manapun dalam struktur kekuassan publik diluar institusi peradilan itu sendiri. ${ }^{8}$

Hakim merupakan unsur utama dalam pengadilan. Bahkan ia identik dengan pengadilan itu sendiri. Kebebasan kekuasaan kehakiman sering kali diidentikkan dengan kebebasan hakim. Demikian halnya, keputusan pengadilan diidentikkan dengan keputusan hakim. Oleh karena itu, pencapaian penegakan hukum dan keadilan terletak pada kemampuan dan kearifan hakim dalam merumuskan keputusan yang mencerminkan keadilan. ${ }^{9}$

\footnotetext{
${ }^{6}$ Diding Rahmat, 2016, "Eksistensi Lembaga Bantuan Hukum (LBH) Cirebon dalam Pendampingan Perkara Pidana di Pengadilan Negeri Cirebon”, Jurnal Ilmu Hukum Vol. 3 No. 1 Januari 2016, Kuningan: FH Uniku, hlm. 1-13.

${ }^{7}$ Yani Andriyani, 2019. Implementasi Kode Etik Hakim Dalam Memeriksa, Mengadili Dan Memutus Perkara, Jurnal Logika Vol. 10 Nomor o1 Juni 2019, Kuningan: FH UNIKU hlm 13-30

8 Komisi Yudisial Republik Indonesia, Bahan Bacaan Klinik Etik dan Hukum, ...h. 70

${ }^{9}$ Aunur Rohim Faqih, 2013. Kode Etik Dan Pedoman Perilaku Hakim, Jurnal Agama dan Hak Azazi Manusia Vol. 3, No. 1, 2013. Yogyakarta: FH UII
} 
Logika : Journal of Multidisciplinary Studies, p-ISSN 2085-997X. e-ISSN 2715-4505.

Vol. 11 Nomor 02 Desember 2020. 68-78.

Untuk menegakkan hukum dan keadilan, seorang hakim mempunyai kewajiban kewajiban atau tanggung jawab hukum. Kewajiban hakim sebagai salah satu organ lembaga peradilan tertuang dalam Undang-Undang Nomor 48 Tahun 2009 tentang Kekuasaan Kehakiman. Adapun kewajiban-kewaiban hakim tersebut dengan berikut : ${ }^{10}$

1. Hakim wajib menggali, mengikuti, dan memahami nilai-nilai hukum dan rasa keadilan yang hidup dalam masyarakat.

2. Dalam mempertimbangkan berat ringannya pidana, hakim wajib memperhatikan pula sifat yang baik jahat dari terdakwa.

3. Seorang hakim wajib mengundurkan diri dari persidangan apabila terikat hubungan sedarah dan semenda sampai derajat ke tiga, atau hubungan suami atau istri sekalipun telah bercerai, dengan ketua, salah seorang hakim anggota jaksa, advokat, atau panitera.

4. Ketua majelis, hakim anggota, wajib mengundurkan diri dari persidangan apabila terikat hubungan kekeluarga sedarah dan semenda sampai derajat ketiga, atau hubungan suami atau istri sekalipun telah bercerai, dengan pihak yang diadili atau advokat.

5. Seorang hakim wajib mengundurkan diri sari persidangan apabila ia mempunyai kepentingan langsung atau tidak langsung dengan perkara yang sedang diperiksa, baik atas kehendaknya sendiri maupun atas bermintaan pihak yang berperkara.

6. Sebelum memangu jabatannya, hakim masing-masing lingkungan peradilan wajib mengucapkan sumpah atau janjinya menurut agamanya.

Selain memiliki kewajiban yang harus dipenuhi Hakim dalam menjalankan tugasnya memiliki tanggung jawab profesi. Tanggung jawab tersebut dapat dibedakan menjadi tiga jenis yaitu : ${ }^{11}$

1. Tanggung jawab moral, Adalah tanggungjawab sesuai dengan nilai-nilai dan normanrma yang berlaku dalam lingkungan kehidupan profesi yang bersangkutan, baik bersifat pribadi maupun kelembagaan bagi suatu lembaga yang merupakan wadah para hakim bersangkutan.

2. Tanggung jawab hukum, adalah tanggung jawab yang menjadi beban hakim untuk dapat melaksanakan tugasnya dengan tidak melanggar rambu-rambu hukum.

3. Tanggung jawab teknis profesi, adalah merupakan tuntutan bagi hakim untuk melaksanakan tugasnya secara profesional sesuai dengan kriteria teknis yang berlaku dalam bidang profesi yang bersangkutan, baik bersifat umum maupun ketentuan khusus dalam lembaga.

\section{B. Pengaturan Kode Etik Hakim}

Seorang hakim dituntut untuk dapat menerima dan mengadili berbagai perkara yang diajukan kepadanya. Bahkan jika menolak sebuah perkara maka seorang hakim dapat dituntut dalam pengadilan yang dianggap secara nyata demi keadilan. Demi tercapainya hukum yang sesuai dengan setiap perkara yang sedang di adili sekalipun perkara tersebut belum ada hukum yang sudah mengikat. Sehingga hakim dengan leluasa bisa menentukan hukum tersebut. Sebagaimana diatur dalam Pasal 10 dan Pasal 14

\footnotetext{
${ }^{10}$ Umi Laili, 2017. Peran Komisi Yudisial Dalam Pengawasan Pelanggaran Kode Etik Dan Pedoman Perilaku Hakim. Jurnal LEGALITAS Volume 2 Nomor 1, Juni 2017. Samarinda : FH UNTAG

${ }^{11}$ ibid
} 
Logika : Journal of Multidisciplinary Studies, p-ISSN 2085-997X. e-ISSN 2715-4505.

Vol. 11 Nomor 02 Desember 2020. 68-78.

Undang-undang Nomor 48 Tahun 2009 Tentang Kekuasaan KehakimanInilah yang dimaksud dari asas hukum asas Ius Curia Novit. ${ }^{12}$

Dalam hal melakukan penegakan kode etik dan perilaku hakim, terdapat beberapa isu yang mencuat dalam pelaksanannya. kode etik dan perilaku hakim di Indonesia bukan merupakan Kode Etik yang operasional seperti negara lain (misalnya merujuk Code of Conduct di New South Wales). Hal ini menyebabkan ada kesulitan dalam penegakan kode etik dan perilaku hakim di Indonesia karena kebingungan mengimplementasikan rumusan kode etik dan perilaku hakim yang terlalu luas. ${ }^{13}$

Kode etik profesi hakim merupakan aturan tertulis yang harus dipedomani oleh setiap hakim Indonesia dalam melaksanakan tugas profesi sebagai hakim. Kode etik dan/atau pedoman perilaku hakim adalah panduan dalam rangka menjaga dan menegakkan kehormatan, keluhuran martabat, serta perilaku hakim dalam menjalankan tugas profesinya dan dalam hubungan kemasyarakatan di luar kedinasan. ${ }^{14}$

Maksud penegakan kode etik dan pedoman perilaku hakim dimaksudkan sebagai acuan dalam rangka menegakkan Kode Etik dan Pedoman Perilaku Hakim dan tujuan penegakan kode etik dan pedoman perilaku hakim bertujuan untuk menciptakan kepastian dan kesepahaman dalam penerapan kode etik dan pedoman perilaku hakim. ${ }^{15}$

Dalam forum International Judicial Conference di Banglore India tahun 2001, berhasil disepakati draft kode etik dan perilaku hakim sedunia yang dikenal dengan The Bongalore Draft yang di dalamnya terkandung 6 (enam) prinsip yang harus dijadikan pegangan bagi hakim secara universal yaitu : ${ }^{16}$

1. Indepedensi (Independence Principle)

2. Ketidakberpihakan (Impartially Prinsiple)

3. Integritas (Integrity Principle)

4. Kepantasan dan kesopanan (Propriety Principle)

5. Kesetaraaan (Equality Principle)

6. Kecakapan dan keseksamaan (Competence and Diligent Principle).

Prinsip-prinsip dasar kode etik dan pedoman perilaku hakim diimplementasikan dalam 10 (sepuluh) aturan perilaku sebagai berikut: ${ }^{17}$

1. Berperilaku Adil, Berperilaku adil bermakna menempatkan sesuatu pada tempatnya dan memberikan yang menjadi haknya, yang didasarkan pada suatu prinsip bahwa semua orang sama kedudukannya di depan hukum. Dengan demikian, tuntutan yang paling mendasar dari keadilan adalah memberikan perlakuan dan memberi kesempatan yang

\footnotetext{
${ }^{12}$ Sutrisno dan Wiwin Yulianingsih, Etika Profesi Hukum, (Yogyakarta : C.v Andy Offset,2016), h. 236

${ }^{13}$ Ismail Rumadan, 2016. Membangun Hubungan Harmonis Dalam Pelaksanaan Fungsi Pengawasan Hakim Oleh Mahkamah Agung Dan Komisi Yudisial Dalam Rangka Menegakkan Kehormatan, Keluhuran Dan Martabat Hakim, Jurnal Hukum dan Peradilan, Volume 5 Nomor 2, Juli 2016. Jakarta: FH Universitas Nasional

${ }^{14}$ Pasal 1 angka 6 Undang-Undang Nomor 18 Tahun 2011 Tentang Komisi Yudisial dan Surat Keputusan Bersama Ketua Mahkamah Agung Republik Indonesia dan Ketua Komisi Yudisial

${ }^{15}$ Pasal 2 Peraturan Bersama Ketua Mahkamah Agung Republik Indonesia DanKetua Komisi Yudisial Republik Indonesia Nomor : 02/PB/MA/IX/2012- 02/PB/P.KY/o9/2012 Tentang Panduan Penegakan Kode Etik Dan Pedoman Perilaku Hakim

${ }^{16}$ Heni Hendrawati, Siti Vickie Dina, dkk, 2016. Aspek Penegakan Kode Etik Hakim Dalam Mewujudkan Kekuasaan Kehakiman Yang Bermartabat Dan Berintegrita, Varia Justicia Vol 12 No. 1 Maret 2016. Magelang: FH Universitas Muhammadiyah Magelang

${ }^{17}$ Pasal 4 dan 5 Peraturan Bersama Ketua Mahkamah Agung Republik Indonesia dan Ketua Komisi

Yudisial Republik Indonesia Nomor : 02/PB/MA/IX/2012- 02/PB/P.KY/o9/2012 Tentang Panduan

Penegakan Kode Etik Dan Pedoman Perilaku Hakim.
} 
sama (equality and fairness) terhadap setiap orang. Oleh karenanya, seseorang yang melaksanakan tugas atau profesi di bidang peradilan yang memikul tanggung jawab menegakkan hukum yang adil dan benar harus selalu berlaku adil dengan tidak membeda-bedakan orang.

2. Berperilaku Jujur, Berperilaku jujur bermakna dapat dan berani menyatakan bahwa yang benar adalah benar dan yang salah adalah salah. Kejujuran mendorong terbentuknya pribadi yang kuat dan membangkitkan kesadaran akan hakekat yang hak dan yang batil. Dengan demikian, akan terwujud sikap pribadi yang tidak berpihak terhadap setiap orang baik dalam persidangan maupun diluar persidangan.

3. Berperilaku Arif dan Bijaksana, Berperilaku arif dan bijaksana bermakna mampu bertindak sesuai dengan norma-norma yang hidup dalam masyarakat baik norma-norma hukum, norma-norma keagamaan, kebiasan-kebiasan maupun kesusilaan dengan memperhatikan situasi dan kondisi pada saat itu, serta mampu memperhitungkan akibat dari tindakannya. Perilaku yang arif dan bijaksana mendorong terbentuknya pribadi yang berwawasan luas, mempunyai tenggang rasa yang tinggi, bersikap hati-hati, sabar dan santun

4. Bersikap Mandiri, Berperilaku mandiri bermakna mampu bertindak sendiri tanpa bantuan pihak lain, bebas dari campur tangan siapapun dan bebas dari pengaruh apapun. Sikap mandiri mendorong terbentuknya perilaku hakim yang tangguh, berpegang teguh pada prinsip dan keyakinan atas kebenaran sesuai tuntutan moral dan ketentuan hukum yang berlaku

5. Berintegritas Tinggi, Berperilaku berintegritas tinggi bermakna memiliki sikap dan kepribadian yang utuh, berwibawa, jujur dan tidak tergoyahkan. Integritas tinggi pada hakekatnya terwujud pada sikap setia dan tangguh berpegang pada nilai-nilai atau norma-norma yang berlaku dalam melaksanakan tugas. Integritas tinggi akan mendorong terbentuknya pribadi yang berani menolak godaan dan segala bentuk intervensi, dengan mengedepankan tuntutan hati nurani untuk menegakkan kebenaran dan keadilan serta selalu berusaha melakukan tugas dengan cara-cara terbaik untuk mencapai tujuan terbaik.

6. Bertanggung Jawab, Berperilaku bertanggungjawab bermakna kesediaan untuk melaksanakan sebaik-baiknya segala sesuatu yang menjadi wewenang dan tugasnya, serta memiliki keberanian untuk menanggung segala akibat atas pelaksanaan wewenang dan tugasnya tersebut.

7. Menjunjung Tinggi Harga Diri, Berperilaku menjunjung harga diri bermakna bahwa pada diri manusia melekat martabat dan kehormatan yang harus dipertahankan dan dijunjung tinggi oleh setiap orang. Prinsip menjunjung tinggi harga diri, khususnya hakim, akan mendorong dan membentuk pribadi yang kuat dan tangguh, sehingga terbentuk pribadi yang senantiasa menjaga kehormatan dan martabat sebagai aparatur Peradilan.

8. Berdisplin Tinggi, Berperilaku disiplin bermakna ketaatan pada norma-norma atau kaidah kaidah yang diyakini sebagai panggilan luhur untuk mengemban amanah serta kepercayaan masyarakat pencari keadilan. Disiplin tinggi akan mendorong terbentuknya pribadi yang tertib di dalam melaksanakan tugas, ikhlas dalam pengabdian 
Logika : Journal of Multidisciplinary Studies, p-ISSN 2085-997X. e-ISSN 2715-4505.

Vol. 11 Nomor 02 Desember 2020. 68-78.

dan berusaha untuk menjadi teladan dalam lingkungannya, serta tidak menyalahgunakan amanah yang dipercayakan kepadanya.

9. Berperilaku Rendah Hati, Berperilaku rendah hati bermakna kesadaran akan keterbatasan kemampuan diri, jauh dari kesempurnaan dan terhindar dari setiap bentuk keangkuhan. Rendah hati akan mendorong terbentuknya sikap realistis, mau membuka diri untuk terus belajar, menghargai pendapat orang lain, menumbuh kembangkan sikap tenggang rasa, serta mewujudkan kesederhanaan, penuh rasa syukur dan ikhlas di dalam mengemban tugas.

10. Bersikap Profesional, Profesional bermakna suatu sikap moral yang dilandasi oleh tekad untuk melaksanakan pekerjaan yang dipilihnya dengan kesungguhan, yang didukung oleh keahlian atas dasar pengetahuan, keterampilan dan wawasan luas. Sikap profesional akan mendorong terbentuknya pribadi yang senantiasa menjaga dan mempertahankan mutu pekerjaan, serta berusaha untuk meningkatkan pengetahuan dan kinerja, sehingga tercapai setinggitingginya mutu hasil pekerjaan, efektif dan efisien.

Adapun beberapa perbuatan yang dilarang dan tidak boleh dilakukan oleh hakim, diantaranya : ${ }^{18}$

1. Hakim dilarang memberikan kesan bahwa salah satu pihak yang tengah berperkara atau kuasanya termasuk penuntut dan saksi berada dalam posisi yang istimewa untuk mempengaruhi hakim yang bersangkutan.

2. Hakim tidak boleh meminta/menerima dan harus mencegah suami atau istri hakim, orang tua, anak atau anggota keluarga hakim lainnya, untuk meminta atau menerima janji, hadiah, hibah, warisan, pemberian, penghargaan dan pinjaman atau fasilitas dari:advokat; penuntut; orang yang sedang diadili; pihak lain yang kemungkinkan kuat akan diadili.

3. Hakim dilarang menggunakan wibawa pengadilan untuk kepentingan pribadi, keluarga atau pihak ketiga lainnya.

4. Hakim dilarang melakukan tawar-menawar putusan, memperlambat pemeriksaan perkara, menunda eksekusi atau menunjuk advokat tertentu dalam menangani suatu perkara di pengadilan, kecuali ditentukan lain oleh undang-undang.

5. Hakim dilarang menggunakan wibawa jabatan sebagai hakim untuk mengejar kepentingan pribadi, anggota keluarga atau siapapun juga dalam hubungan finansial.

Apabila hakim melakukan perbuatan yang dilarang tersebut, maka hakim dapat dikatakan melakukan pelanggaran. Pelanggaran adalah setiap sikap, ucapan, dan/atau perbuatan yang dilakukan oleh seorang hakim yang bertentangan dengan norma-norma yang ditentukan dalam kode etik dan pedoman perilaku hakim. ${ }^{19}$ Seorang hakim yang terbukti melakukan pelanggaran terhadap kode etik akan dikenakan sanksi. Sanksi terdiri dari: sanksi ringan, sanksi sedang dan sanksi berat.

\footnotetext{
${ }^{18}$ Pasal 5 s.d pasal ${ }_{11}$ Peraturan Bersama Ketua Mahkamah Agung Republik Indonesia dan Ketua Komisi Yudisial Republik Indonesia Nomor : 02/PB/MA/IX/2012- 02/PB/P.KY/o9/2012 Tentang Panduan Penegakan Kode Etik Dan Pedoman Perilaku Hakim

${ }^{19}$ Pasal 1 Angka 6 Peraturan Bersama Ketua Mahkamah Agung Republik Indonesia dan Ketua Komisi Yudisial Republik Indonesia Nomor : 02/PB/MA/IX/2012- 02/PB/P.KY/o9/2012 Tentang Panduan Penegakan Kode Etik Dan Pedoman Perilaku Hakim
} 
Logika : Journal of Multidisciplinary Studies, p-ISSN 2085-997X. e-ISSN 2715-4505.

Vol. 11 Nomor 02 Desember 2020. 68-78.

1. Sanksi ringan terdiri dari: $:^{20}$
a. Teguran lisan;
b. Teguran tertulis;
c. Pernyataan tidak puas secara tertulis.

2. Sanksi sedang terdiri dari:
a. Penundaan kenaikan gaji berkala paling lama 1 (satu) tahun;
b. Penurunan gaji sebesar 1 (satu) kali kenaikan gaji berkala paling
c. lama 1 (satu) tahun;
d. Penundaan kenaikan pangkat paling lama 1 (satu) tahun;
e. Hakim nonpalu paling lama 6 (enam) bulan;
f. Mutasi ke pengadilan lain dengan kelas yang lebih rendah;
g. Pembatalan atau penangguhan promosi.

3. Sedangkan sanksi berat terdiri dari:
a. Pembebasan dari jabatan;
b. Hakim nonpalu lebih dari 6 (enam) bulan dan paling lama 2 (dua)
c. tahun; penurunan pangkat pada pangkat yang setingkat lebih rendah
d. untuk paling lama 3 (tiga) tahun;
e. Pemberhentian tetap dengan hak pensiun;
f. Pemberhentian tidak dengan hormat.

Hakim nonpalu adalah hakim yang dijatuhi sanksi tidak diperkenankan memeriksa dan mengadili perkara dalam tenggang waktu tertentu. ${ }^{21}$ Pemberhentian adalah pemberhentian dengan hormat atau pemberhentian tidak dengan hormat sedangkan Pemberhentian sementara adalah pemberhentian untuk waktu tertentu terhadap seorang hakim sebelum adanya putusan pengadilan dalam perkara pidana yang dijalaninya berkekuatan hukum tetap atau keputusan pemberhentian tetap sesuai dengan peraturan perundang-undangan, sementara yang dimaksud dengan pemberhentian tetap dengan hak pensiun sebagaimana dimaksud dengan Undang-Undang Nomor 18 Tahun 2011 tentang Perubahan Atas UndangUndang Nomor 22 Tahun 2004 tentang Komisi Yudisial, dimaknai sebagai pemberhentian dengan hormat. ${ }^{22}$

\section{Studi Kasus Pelanggaran Kode Etik Hakim}

Agar independensi seorang hakim selalu terjaga, maka seorang hakim dituntut untuk secara intensif memerhatikan kejujuran dan integritasnya. Sebab hal ini adalah fondasi keadilan yang harus selalu ditegakkan. Orang-orang yang berperkara terkadang berusaha merusak integritas hakim yang menangani perkara mereka dengan berbagai cara. Untuk mencapai tujuan itu orang-orang tersebut akan mencari cara agar mereka mendapat

\footnotetext{
${ }^{20}$ Pasal 19 Peraturan Bersama Ketua Mahkamah Agung Republik Indonesia dan Ketua Komisi Yudisial Republik Indonesia Nomor : 02/PB/MA/IX/2012- 02/PB/P.KY/09/2012 Tentang Panduan Penegakan Kode Etik Dan Pedoman Perilaku Hakim

${ }^{21}$ Pasal 1 Angka 15 Peraturan Bersama Ketua Mahkamah Agung Republik Indonesia dan Ketua Komisi Yudisial Republik Indonesia Nomor : 02/PB/MA/IX/2012- 02/PB/P.KY/o9/2012 Tentang Panduan Penegakan Kode Etik Dan Pedoman Perilaku Hakim

${ }^{22}$ Pasal 1 Angka 16, 17 dan 18 Peraturan Bersama Ketua Mahkamah Agung Republik Indonesia dan Ketua Komisi Yudisial Republik Indonesia Nomor : 02/PB/MA/IX/2012- 02/PB/P.KY/o9/2012 Tentang Panduan Penegakan Kode Etik Dan Pedoman Perilaku Hakim
} 
Logika : Journal of Multidisciplinary Studies, p-ISSN 2085-997X. e-ISSN 2715-4505.

Vol. 11 Nomor 02 Desember 2020. 68-78.

kesempatan untuk menjalin hubungan dengan hakim. Orang-orang tersebut merusak integritas hakim dengan mendapatkan kemurahan hati yang tidak semestinya dalam persidangan, dan mengeksploitasi hubungan mereka dengan hakim.

Hakim sebagai salah satu aparat penegak hukum (legal aparatus) yang sudah memiliki kode etik sebagai standar moral atau kaedah seperangkat hukum formal. Namun realitanya para kalangan profesi hukum belum menghayati dan melaksanakan kode etik profesi dalam melaksanakan profesinya sehari-hari, terlihat dengan banyaknya yang mengabaikan kode etik profesi, sehingga profesi ini tidak lepas mendapat penilaian negatif dari masyarakat. ${ }^{23}$

Akhir September 2019, Mahkamah Agung memutuskan bahwa hakim adhoc Tindak Pidana Korupsi, Syamsul Rakan Chaniago terbukti melanggar kode etik dan perilaku hakim. Yaitu dengan sengaja melakukan kontak hubungan dan mengadakan pertemuan dengan penasihat hukum Syafruddin Temenggung pada saat dirinya sedang menjadi hakim kasasi perkara Surat Keterangan Lunas Bantuan Bank Likuiditas Indonesia, SKL BLBI. Pelanggaran Kode Etik dan Pedoman Perilaku Hakim 2009 yang telah melarang tegas, Seorang hakim harus berperilaku adil dan harus menghindari hal-hal yang dapat mengakibatkan pencabutan haknya mengadili perkara yang bersangkutan. Sebagaimana dijelaskan dalam Pasal 17 Ayat (5) Undang-Undang Kekuasaan Kehakiman menegaskan larangan. "Seorang hakim atau panitera wajib mengundurkan diri dari persidangan apabila ia mempunyai kepentingan langsung atau tidak langsung dengan perkara yang sedang diperiksa, baik atas kehendaknya sendiri maupun atas permintaan pihak yang berperkara". Dan sesuai dengan apa yang termuat dalam Pasal 17 Ayat (6) "Dalam hal terjadi pelanggaran terhadap ketentuan sebagaimana dimaksud pada ayat (5), putusan dinyatakan tidak sah dan terhadap hakim atau panitera yang bersangkutan dikenakan sanksi administratif atau dipidana sesuai dengan ketentuan peraturan perundang- undangan. Oleh Karena itu atas alasan tersebut Syamsul Rakan Chaniago dikenakan sanksi etik. Yaitu sanksi sedang berupa hakim non palu selama 6 bulan sebagaimana diatur dalam Pasal 21 huruf b Peraturan Bersama Ketua MA dan Ketua KY No. 02/PB/MA/IX/2012 - 02 /BP/P-KY/o9/2012. Hukuman non palu itu efektif sejak Syamsul menerima pemberitahuan dari MA.

\section{SIMPULAN}

Kode Etik hakim merupakan panduan sehingga para profesional hukum bisa diharapkan memiliki kualitas diri yang menjadi acuan terhadap penilaian dan sikap moralnya dalam melaksankan tugas dalam profesinya. Kode etik sudah dilaksankan dan ditegakan maka dengan itu keadilan pun akan tercipta demi kesalarasan hukum yang bersifat netral dan menjungjung harga diri dan martabat hakim sehingga Kode Etik dan Pedoman Perilaku Hakim bisa dijalankan dengan semestinya.

\section{SARAN}

Kepada semua hakim yang ada di Indonesia baik di Pengadilan Negeri, Pengadilan Agama, Pengadilan Militer dan maupun Pengadilan PTUN agar mematuhi semua Kode Etik dan Pedoman Perilaku Hakim yang Berlaku. Agar dapat memberikan keadilan yang seadil-adilnya, agar tercipta kesejahteraan bagi seluruh masyarakat

\footnotetext{
${ }^{23}$ Sakirman,2017. Analisis profesi hakim dalam epistemology hukum Islam, Ijtihad, Jurnal Wacana Hukum Islam dan Kemanusiaan, Volume 17, No. 1, Juni 2017: 137-154. Lampung: IAIN Lampung
} 
Logika : Journal of Multidisciplinary Studies, p-ISSN 2085-997X. e-ISSN 2715-4505.

Vol. 11 Nomor 02 Desember 2020. 68-78.

\section{DAFTAR PUSTAKA}

Jurnal:

Achmad Miftah Farid, Hibnu Nugroho, Dwi Hapsari Retnaningrum, 2020. Pelaksanaan Fungsi Pengawasan Terhadap Perilaku Hakim Oleh Mahkamah Agung, Soedirman Law Review, Volume 2 No. 1 Tahun 2020. Purwokerto : FH UNSOED

Aunur Rohim Faqih, 2013. Kode Etik Dan Pedoman Perilaku Hakim, Jurnal Agama dan Hak Azazi Manusia Vol. 3, No. 1, 2013. Yogyakarta: FH UII

Diding Rahmat, 2016, “Eksistensi Lembaga Bantuan Hukum (LBH) Cirebon dalam Pendampingan Perkara Pidana di Pengadilan Negeri Cirebon", Jurnal Ilmu Hukum Vol. 3 No. 1 Januari 2016, Kuningan: FH Uniku, hlm. 1-13.

Firman Floranta Adonara, 2015. Prinsip Kebebasan Hakim Dalam Memutus Perkara Sebagai Amanat Konstitusi, Jurnal Konstitusi, Volume 12, Nomor 2, Juni $2015 . \quad$ Jember:

FH Universitas Jember

H. Sudirman L, Hasanuddin Hasim, Abdul Hafid, 2019. Implementasi Kode Etik Dan Pedoman Perilaku Hakim Di Ptun Makassar. Jurnal Hukum Samudra Keadilan Volume 14, Nomor 2, Juli-Desember 2019. Parepare : FHIS IAIN Parepare

Heni Hendrawati, Siti Vickie Dina, dkk, 2016. Aspek Penegakan Kode Etik Hakim DalamMewujudkan Kekuasaan Kehakiman Yang Bermartabat Dan Berintegrita, Varia Justicia Vol 12 No. 1 Maret 2016. Magelang: FH Universitas Muhammadiyah Magelang

Ismail Rumadan, 2016. Membangun Hubungan Harmonis Dalam Pelaksanaan Fungsi Pengawasan Hakim Oleh Mahkamah Agung Dan Komisi Yudisial Dalam Rangka Menegakkan Kehormatan, Keluhuran Dan Martabat Hakim, Jurnal Hukum dan Peradilan, Volume 5 Nomor 2, Juli 2016. Jakarta: FH Universitas Nasional

Umi Laili, 2017. Peran Komisi Yudisial Dalam Pengawasan Pelanggaran Kode Etik Dan Pedoman Perilaku Hakim. Jurnal LEGALITAS Volume 2 Nomor 1, Juni 2017. Samarinda : FH UNTAG

Sakirman,2017. Analisis profesi hakim dalam epistemology hukum Islam, Ijtihad, Jurnal Wacana Hukum Islam dan Kemanusiaan, Volume 17, No. 1, Juni 2017: 137-154. Lampung: IAIN Lampung

Yani Andriyani, 2019. Implementasi Kode Etik Hakim Dalam Memeriksa, Mengadili Dan Memutus Perkara, Jurnal Logika Vol. 10 Nomor o1 Juni 2019, Kuningan: FH UNIKU hlm 13-30

\section{Buku- Buku:}

Al Wisnubroto, 1997, Hakim Dan Peradilan Di Indonesia, Universitas AtmaJaya Yogyakarta, Yogyakarta, hlm. 65

Komisi Yudisial Republik Indonesia, Bahan Bacaan Klinik Etik dan Hukum, ...h. 70

Sutrisno dan Wiwin Yulianingsih, Etika Profesi Hukum, (Yogyakarta : C.v Andy Offset,2016), h. 236

Internet : 
Logika : Journal of Multidisciplinary Studies, p-ISSN 2085-997X. e-ISSN 2715-4505.

Vol. 11 Nomor 02 Desember 2020. 68-78.

Devina Halim, KY Ungkap Dua Alasan Maraknya Pelanggaran Hakim, diakses di https://nasional.kompas.com/read/2018/og/o6/21011321/ky-ungkap-duaalasan- $\quad$ maraknya-pelanggaran-hakim, pada pukul 14.20 WIB 14 April 2020.

\section{Perundang-Undangan :}

Undang-Undang Dasar 1945

Undang-Undang Nomor 48 tahun 2009 tentang Kekuasaan Kehakiman

Undang-Undang Nomor 18 Tahun 2011 Tentang Komisi Yudisial

Peraturan Bersama Ketua Mahkamah Agung Republik Indonesia Dan Ketua Komisi Yudisial Republik Indonesia Nomor : 02/PB/MA/IX/2012- 02/PB/P.KY/09/2012 Tentang Panduan Penegakan Kode Etik Dan Pedoman Perilaku Hakim

Surat Keputusan Bersama Ketua Mahkamah Agung Republik Indonesia dan Ketua Komisi Yudisial Republik Indonesia Nomor: 047/KMA/SKB/IV/2009 02/SKB/P.KY/IV/2009 tanggal 8 April 2009 Tentang Kode Etik dan Pedoman Perilaku Hakim 